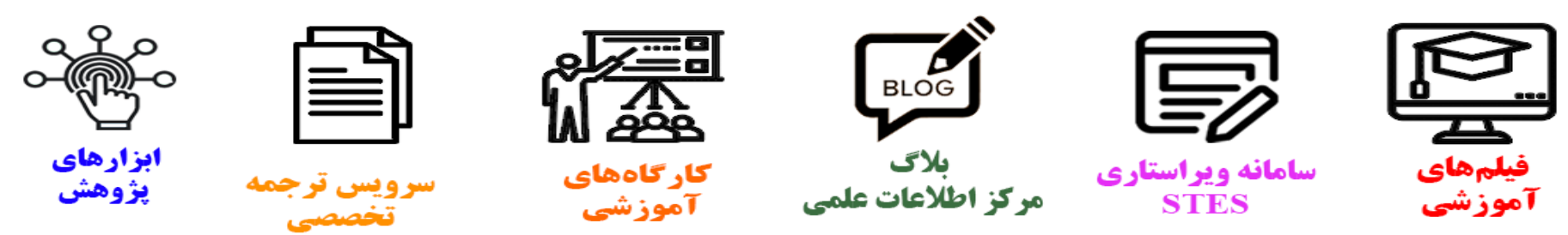

\title{
(c)
}

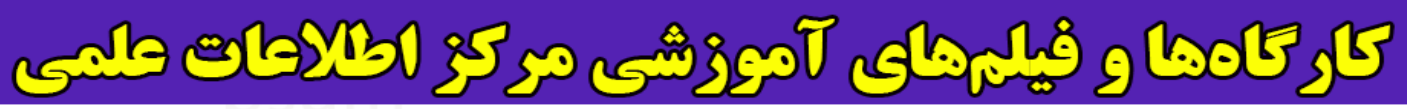
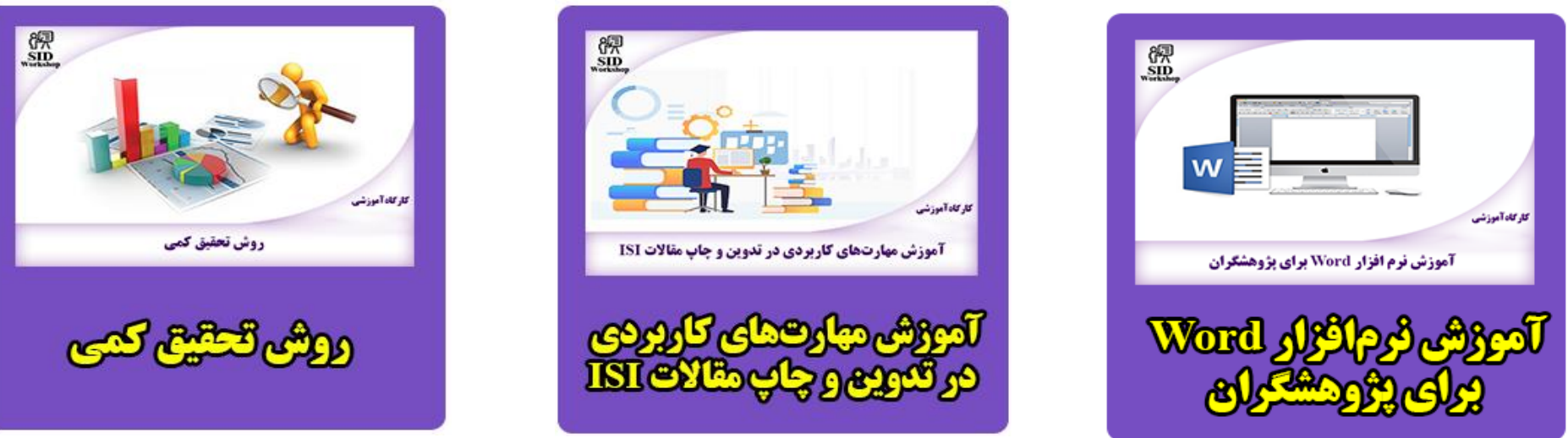


\title{
International Journal of Engineering
}

Journal Hom e page: ww w. i je.ir

\section{The Effect of Variable Properties on Rayleigh-Benard Convection in an Enclosure Filled with $\mathrm{Al}_{2} \mathrm{O}_{3}$-EG-Water Nanofluid}

\author{
G. A. Sheikhzadeh*, S. P. Ghaffari, M. M. Fakhari \\ Department of Mechanical Engineering and Energy Research Institute, University of Kashan, Kashan, Iran
}

\section{$P A P E R \quad I N F O$}

Paper history:

Received 24 March 2013

Received in revised form 16 May 2013

Accepted 20 June 2013

\section{Keywords:}

Nanofluid

Variable properties

Rayleigh-Benard convection

$\mathrm{Al}_{2} \mathrm{O}_{3}$-Ethylene Glycol-water

Enclosure

\section{$A B S T R A C T$}

In this paper, the natural convection heat transfer of $\mathrm{Al}_{2} \mathrm{O}_{3}$-EG-water nanofluid in a rectangular cavity heated from the bottom and cooled from the top has been investigated numerically. The governing equations for a Newtonian fluid have been solved numerically with a finite volume approach using the SIMPLER algorithm. The main focus of the current study is on the effects of the variable thermophysical properties of nanofluid on the natural convection heat transfer. The influence of pertinent parameters such as Rayleigh number $\left(\mathrm{Ra}=10^{5}-10^{7}\right)$ and volume fractions of nanoparticles $(0 \leq \Phi \leq 0.05)$ on the heat transfer characteristics of natural convection have been studied. The results have shown that the average Nusselt number is reduced by increasing the volume fraction of nanoparticles. To study the significance of temperature effect on thermophysical properties of nanofluid, the results obtained by using variable properties of nanofluid are compared with those of constant properties.

doi: $10.5829 /$ idosi.ije.2013.26.12c.02

\begin{tabular}{|c|c|c|c|}
\hline \multicolumn{4}{|c|}{ NOMENCLATURE } \\
\hline$c_{\mathrm{p}}$ & Specific heat at constant pressure (J/kg K) & $\kappa$ & Boltzmann constant, $1.3806503 \times 10^{-23},(\mathrm{~J} / \mathrm{K})$ \\
\hline $\mathrm{d}$ & Diameter (m) & $\mu$ & Viscosity (Pa s) \\
\hline $\mathrm{g}$ & Gravitational acceleration $\left(\mathrm{m} / \mathrm{s}^{2}\right)$ & $\xi$ & Ethylene-Glycol volumetric concentration \\
\hline $\mathrm{h}$ & Heat transfer coefficient $\left(\mathrm{W} / \mathrm{m}^{2} \mathrm{~K}\right)$ & $\rho$ & Density (kg/m) \\
\hline $\mathrm{H}$ & The height of the cavity (m) & $\Phi$ & Volume fraction of nanoparticles \\
\hline $\mathrm{k}$ & Thermal conductivity (W/m K) & $\psi$ & Stream function \\
\hline $\mathrm{L}$ & The length of the cavity (m) & \multicolumn{2}{|c|}{ Subscripts } \\
\hline $\mathrm{Nu}$ & Nusselt number & avg & Average over the cavity length \\
\hline $\mathrm{P}$ & Pressure $(\mathrm{Pa})$ & $\mathrm{C}$ & Cold \\
\hline $\operatorname{Pr}$ & Prandtl number & EG & Ethylene-Glycol \\
\hline $\mathrm{Ra}$ & Rayleigh number & $\mathrm{f}$ & Base fluid \\
\hline $\mathrm{T}$ & Temperature (K) & $\mathrm{H}$ & Hot \\
\hline$u, v$ & Dimensional $\mathrm{x}$ and $\mathrm{y}$ components of velocity $(\mathrm{m} / \mathrm{s})$ & $\mathrm{nf}$ & Nanofluid \\
\hline$x, y$ & Dimensional coordinates $(\mathrm{m})$ & o & Properties at reference temperature, $300 \mathrm{~K}$ \\
\hline $\mathrm{X}, \mathrm{Y}$ & Dimensionless coordinates & $\mathrm{p}$ & Nanoparticle \\
\hline \multicolumn{2}{|c|}{ Greek Symbols } & $\mathrm{w}$ & Water \\
\hline$\alpha$ & Thermal diffusivity $\left(\mathrm{m}^{2} / \mathrm{s}\right)$ & \multicolumn{2}{|c|}{ Superscripts } \\
\hline$\beta$ & Thermal expansion coefficient $(1 / \mathrm{K})$ & $*$ & Dimensionless properties \\
\hline$\theta$ & Dimensionless temperature & & \\
\hline
\end{tabular}

*Corresponding Author Email: sheikhz@kashanu.ac.ir (G. A. Sheikhzadeh) 


\section{INTRODUCTION}

During the last two decades, nanofluids which are engineered colloids composed of nanometer-sized particles suspended in traditional heat transfer fluids have been studied extensively to enhance heat transfer. Remarkable increase in thermal conductivity relative to the ordinary fluids can be achieved even at low volume fraction of nanoparticles. Nanofluids have attracted the attention of the heat transfer community. Experimental and numerical results show that in forced convection, for a given Reynolds number the convective heat transfer coefficient increases by increasing the particles volume fraction [1-3]. However, using nanofluids for natural convection heat transfer enhancement is still controversial and there is a debate on the role of nanoparticles on heat transfer enhancement in natural convection applications.

Examples of the controversial results are found in those reported by Khanafer et al. [4] who were among the first investigators to conduct a numerical study of the natural convection heat transfer inside a rectangular cavity filled with a nanofluid. The reported results showed that the heat transfer coefficient was improved with an increase in the volume fraction of nanoparticles for the considered range of Grashof numbers. Recently, Arefmanesh et al. [5], Sheikhzadeh et al. [6] and Sheikhzadeh et al. [7] showed similar trend, where an enhancement in heat transfer was registered by the addition of nanoparticles. Hwang et al. [8] studied free convection using rectangular cavity heated from below (Rayleigh-Bénard convection) with nanofluids. They used convective heat transfer empirical formulas to estimate the heat transfer coefficient of nanofluids and reported an adverse effect of nanoparticles on heat transfer in natural convection regime. However, Kim et al. [9] studied analytically convective instability of nanofluids in natural convection via Rayleigh-Bénard convection and reported an enhancement in convective heat transfer coefficient due to the presence of nanoparticles. Aminossadati and Ghasemi [10] studied natural convection cooling of a heat source embedded on the bottom wall of an enclosure filled with nanofluids numerically. Their results indicated that adding nanoparticles into pure water improves its cooling performance especially at low Rayleigh numbers; but at $\mathrm{Ra}=10^{6}$, a slight increase was observed for the Nusselt number with the solid volume fraction for $\mathrm{Cu}$ and $\mathrm{Ag}$ nanoparticles, whereas, for $\mathrm{Al}_{2} \mathrm{O}_{3}$ and $\mathrm{TiO}_{2}$, optimum values can be found for solid volume fraction which result in the highest cooling performance. Santra et al. [11] studied heat transfer characteristics of copper-water nanofluid in a differentially heated square cavity by treating the nanofluid as a non-Newtonian fluid and they reported a decrease in heat transfer by increasing the volume fraction of nanoparticles for a particular Rayleigh number. Ho et al. [12] reported a numerical simulation of natural convection of nanofluid in a square enclosure considering the effects due to uncertainties of viscosity and thermal conductivity by considering two models for viscosity and thermal conductivity. They reported that significant difference between the enhancements in the viscosity models leads to contradictory heat transfer efficacy of the nanofluid, so that the heat transfer across the enclosure can be found to be enhanced or deteriorated with respect to the base fluid. Experimentally, the findings reported by Wen and Ding [13], Putra et al. [14] and Li and Peterson [15] highlighted deterioration in heat transfer by the addition of nanoparticles. Also, Ho et al. [16] observed a deterioration in heat transfer for volume fraction of nanoparticles $\Phi>0.02$; However, they reported an enhancement for volume fraction of $0.001 \quad(18 \%$ enhancement) and did not give an explanation for such an enhancement. Similar observations have been reported experimentally by Agwu Nnanna [17]. Therefore, it seems that experimental studies observed deterioration in heat transfer at high volume fraction of nanoparticles. As a result, there is still a controversy on the role of nanofluids in natural convection heat transfer. Khanafer and Vafai [18] used the experimental results of Ho et al. [16] to explain the heat transfer behavior of $\mathrm{Al}_{2} \mathrm{O}_{3}$-water nanofluid. According to their findings, higher volume fractions of nanoparticles cause an increase in the viscous force of the nanofluid and consequently suppress heat transfer. Also, as the particles diameter increases the ratio of the Rayleigh number of nanofluid to that of the base fluid decreases; thus the natural convection heat transfer reduces with an increase in the volume fraction of nanoparticles at room temperature. Also, the ratio of nanofluid Rayleigh number to the base fluid Rayleigh number increases with an increase in the temperature. According to their results, for volume fraction of 0.01 , nanofluid Rayleigh number is smaller than the Rayleigh number of water below $31^{\circ} \mathrm{C}$. But for temperatures greater than $31^{\circ} \mathrm{C}$, nanofluid Rayleigh number is higher than that of water. Hence, natural convection heat transfer enhancement using the nanofluids occurs at high temperatures. Although Khanafer and Vafai [18] were successful to explain some heat transfer behaviors of $\mathrm{Al}_{2} \mathrm{O}_{3}$-water nanofluid, they mentioned: "Additional theoretical and experimental research studies are required to clarify the mechanisms responsible for heat transfer enhancement in nanofluids."

Almost all of the aforementioned numerical works relied on the nanofluid thermophysical properties models that are not sensitive to the fluid temperature. Recently, Abu-Nada [19] studied the heat transfer enhancement using $\mathrm{CuO}$-water nanofluid in natural convection using the Rayleigh-Bénard convection 
problem. They studied the effects of variable thermal conductivity and viscosity of nanofluids on heat transfer enhancement in natural convection. According to their results, for $\mathrm{Ra}>10^{3}$, the average Nusselt number was reduced by increasing the volume fraction of nanoparticles. However, for $\mathrm{Ra}=10^{3}$, the average Nusselt number was enhanced by increasing the volume fraction of nanoparticles. They found that for $\mathrm{Ra}>10^{3}$ the average Nusselt number was much more sensitive to the viscosity models than to the thermal conductivity models. Abu-Nada and Chamkha [20] studied the natural convection heat transfer characteristics in a differentially-heated enclosure filled with a CuO-EGwater nanofluid for different variable thermal conductivity and variable viscosity models. Their results showed different behaviors (enhancement or deterioration) in the average Nusselt number as the volume fraction of nanoparticles increased depending on the combination of $\mathrm{CuO}-\mathrm{EG}$-water variable thermal conductivity and viscosity models employed. Recently, Sahoo et al. [21], Vajjha and Das [22, 23] and Vajjha et al. [24] experimentally demonstrated the effect of temperature on thermophysical properties of different nanofluids under a wide range of temperatures. The nanofluids used in their experiments were the mixture of 60:40 (by mass) EG-water containing $\mathrm{Al}_{2} \mathrm{O}_{3}, \mathrm{Sb}_{2} \mathrm{O}_{5}$, $\mathrm{SnO}_{2}, \mathrm{ZnO}, \mathrm{CuO}$ and $\mathrm{SiO}_{2}$ nanoparticles. Therefore, from physical point of view the dependence of nanofluid properties on temperature and volume fraction of nanoparticles is very important and to predict the role of nanoparticles in the heat transfer it must be taken into account.

The present numerical study tries to clarify the reason for existing controversies about the results presented in the literature on the heat transfer behavior of nanofluids in natural convection. Also, the scope of the current work is further examination of the sensitivity of natural convection heat transfer to variable properties of $\mathrm{Al}_{2} \mathrm{O}_{3}$-EG-water nanofluid. The detailed experimental results reported by [21-24] have been used for thermophysical properties of the nanofluid. The heat transfer characteristics have been evaluated for a wide range of Rayleigh numbers and volume fraction of nanoparticles. Also, the results have been compared with the old models of nanofluids thermophysical properties which are invariant with respect to temperature.

\section{PROBLEM STATEMENT AND BOUNDARY CONDITIONS}

A schematic view of the cavity considered in the present study is shown in Figure 1. The length and the height of the cavity are denoted by $L$ and $H(L=H)$, respectively. The top wall of the cavity is kept at a constant temperature $\left(\mathrm{T}_{\mathrm{C}}\right)$ lower than the bottom hot wall temperature $\left(\mathrm{T}_{\mathrm{H}}\right)$ at each Rayleigh number. The boundary conditions are:

$$
\begin{aligned}
& u=v=\partial \mathrm{T} / \partial \mathrm{x}=0 \text { at } 0 \leq \mathrm{y} \leq \mathrm{H} \text { and } \mathrm{x}=0, \mathrm{~L} \\
& u=v=0, \mathrm{~T}=\mathrm{T}_{\mathrm{H}} \text { at } \mathrm{y}=0 \text { and } 0 \leq \mathrm{x} \leq \mathrm{L} \\
& u=v=0, \mathrm{~T}=\mathrm{T}_{\mathrm{C}} \text { at } \mathrm{y}=\mathrm{H} \text { and } 0 \leq \mathrm{x} \leq \mathrm{L}
\end{aligned}
$$

The fluid in the enclosure is a mixture of 60:40 (by mass) Ethylene-Glycol and water containing $\mathrm{Al}_{2} \mathrm{O}_{3}$ nanoparticles. The nanofluid is assumed incompressible and the flow is considered two-dimensional and laminar. The density variation in the nanofluid is approximated by the Boussinesq model. In temperature range of 273 to $363 \mathrm{~K}$, the nanofluid behaves as a Newtonian fluid [21]. In this study, the simulations are in the temperature range greater than $300 \mathrm{~K}$; so the nanofluid is considered Newtonian.

\section{MATHEMATICAL FORMULATION}

The EG-water mixture and nanoparticles are assumed in thermal equilibrium and no slip occurs between the two media. So, the governing equations for the laminar and steady state natural convection using variable properties are given as:

Continuity:

$\frac{\partial\left(\rho_{\mathrm{nf}} u\right)}{\partial \mathrm{x}}+\frac{\partial\left(\rho_{\mathrm{nf}} v\right)}{\partial \mathrm{y}}=0$

$\mathrm{x}$-momentum equation:

$\frac{\partial}{\partial x}\left(\rho_{\mathrm{nf}} u u\right)+\frac{\partial}{\partial y}\left(\rho_{\mathrm{nf}} v u\right)=-\frac{\partial \mathrm{p}}{\partial x}+\frac{\partial}{\partial x}\left(\mu_{\mathrm{nf}} \frac{\partial u}{\partial x}\right)+\frac{\partial}{\partial y}\left(\mu_{\mathrm{nf}} \frac{\partial u}{\partial y}\right)$

$\mathrm{y}$-momentum equation:

$\frac{\partial}{\partial x}\left(\rho_{\mathrm{nf}} u v\right)+\frac{\partial}{\partial y}\left(\rho_{\mathrm{nf}} V V\right)=-\frac{\partial \mathrm{p}}{\partial y}+\frac{\partial}{\partial x}\left(\mu_{\mathrm{nf}} \frac{\partial v}{\partial x}\right)+\frac{\partial}{\partial y}\left(\mu_{\mathrm{nf}} \frac{\partial v}{\partial y}\right)$

$+\mathrm{g}\left(\mathrm{T}-\mathrm{T}_{\mathrm{C}}\right)\left(\rho_{\mathrm{nf}} \beta_{\mathrm{nf}}\right)$

Energy equation:

$\frac{\partial}{\partial x}\left(\rho_{\mathrm{nf}} \mathrm{uT}\right)+\frac{\partial}{\partial y}\left(\rho_{\mathrm{nf}} \mathrm{VT}\right)=\frac{\partial}{\partial x}\left(\frac{\mathrm{k}}{\mathrm{c}_{\mathrm{p}}} \frac{\partial \mathrm{T}}{\partial x}\right)+\frac{\partial}{\partial y}\left(\frac{\mathrm{k}}{\mathrm{c}_{\mathrm{p}}} \frac{\partial \mathrm{T}}{\partial y}\right)$

To rewrite the dimensional form of the equations in the nondimensional form, the following nondimensional variables are used:

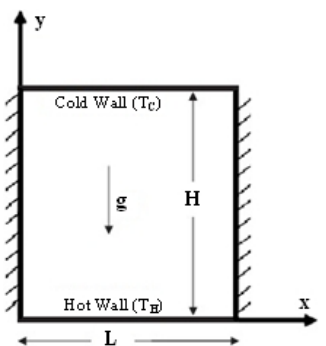

Figure 1. A schematic diagram of the physical model. 
$\mathrm{X}=\mathrm{x} / \mathrm{H}, \quad \mathrm{Y}=\mathrm{y} / \mathrm{H}, \quad \mathrm{U}=u \mathrm{H} / \alpha_{\mathrm{f}, \mathrm{o}}, \quad \mathrm{V}=v \mathrm{H} / \alpha_{\mathrm{f}, \mathrm{o}}$

$\mathrm{P}=\frac{\mathrm{pH}^{2}}{\rho_{\mathrm{f}, \mathrm{o}} \alpha_{\mathrm{f}, \mathrm{o}}{ }^{2}}, \quad \theta=\frac{\mathrm{T}-\mathrm{T}_{\mathrm{C}}}{\mathrm{T}_{\mathrm{H}}-\mathrm{T}_{\mathrm{C}}}, \quad \rho^{*}=\frac{\rho_{\mathrm{nf}}}{\rho_{\mathrm{f}, \mathrm{o}}}$,

$\mu^{*}=\frac{\mu_{\mathrm{nf}}}{\mu_{\mathrm{f}, \mathrm{o}}}, \quad \mathrm{k}^{*}=\frac{\mathrm{k}_{\mathrm{nf}}}{\mathrm{k}_{\mathrm{f}, \mathrm{o}}}, \quad \mathrm{c}_{\mathrm{p}}^{*}=\frac{\mathrm{c}_{\mathrm{pnf}}}{\mathrm{c}_{\mathrm{pf}, \mathrm{o}}}$

Using the above dimensionless variables, the nondimensional forms of the governing equations are:

$\frac{\partial\left(\rho^{*} \mathrm{U}\right)}{\partial \mathrm{X}}+\frac{\partial\left(\rho^{*} \mathrm{~V}\right)}{\partial \mathrm{Y}}=0$

$\frac{\partial}{\partial \mathrm{X}}\left(\rho^{*} \mathrm{UU}\right)+\frac{\partial}{\partial \mathrm{Y}}\left(\rho^{*} \mathrm{VU}\right)=-\frac{\partial \mathrm{P}}{\partial \mathrm{X}}+\operatorname{Pr}_{\mathrm{o}} \frac{\partial}{\partial \mathrm{X}}\left(\mu^{*} \frac{\partial \mathrm{U}}{\partial \mathrm{X}}\right)+\operatorname{Pr}_{\mathrm{o}} \frac{\partial}{\partial \mathrm{Y}}\left(\mu^{*} \frac{\partial \mathrm{U}}{\partial \mathrm{Y}}\right)$

$\frac{\partial}{\partial X}\left(\rho^{*} \mathrm{UV}\right)+\frac{\partial}{\partial \mathrm{Y}}\left(\rho^{*} \mathrm{VV}\right)=-\frac{\partial \mathrm{P}}{\partial \mathrm{Y}}$

$+\operatorname{Pr}_{\mathrm{o}} \frac{\partial}{\partial \mathrm{X}}\left(\mu^{*} \frac{\partial \mathrm{V}}{\partial \mathrm{X}}\right)+\operatorname{Pr}_{\mathrm{o}} \frac{\partial}{\partial \mathrm{Y}}\left(\mu^{*} \frac{\partial \mathrm{V}}{\partial \mathrm{Y}}\right)+\operatorname{Ra} \cdot \operatorname{Pr}_{\mathrm{o}} \cdot \theta\left(\rho^{*} \beta^{*}\right)$

$\frac{\partial}{\partial \mathrm{X}}\left(\rho^{*} \mathrm{U} \theta\right)+\frac{\partial}{\partial \mathrm{Y}}\left(\rho^{*} \mathrm{~V} \theta\right)=\frac{\partial}{\partial \mathrm{X}}\left(\frac{\mathrm{k}^{*}}{\mathrm{c}_{\mathrm{p}}^{*}} \frac{\partial \theta}{\partial \mathrm{X}}\right)+\frac{\partial}{\partial \mathrm{Y}}\left(\frac{\mathrm{k}^{*}}{\mathrm{c}_{\mathrm{p}}^{*}} \frac{\partial \theta}{\partial \mathrm{Y}}\right)$

where the dimensionless numbers of Rayleigh and Prandtl are:

$\operatorname{Pr}_{\mathrm{o}}=\frac{\mu_{\mathrm{f}, \mathrm{o}} \mathrm{c}_{\mathrm{p}_{\mathrm{f}, \mathrm{o}}}}{\mathrm{k}_{\mathrm{f}, \mathrm{o}}}, \quad \mathrm{Ra}=\frac{\mathrm{g} \beta_{\mathrm{f}, \mathrm{o}} \mathrm{H}^{3}\left(\mathrm{~T}_{\mathrm{H}}-\mathrm{T}_{\mathrm{C}}\right)}{\alpha_{\mathrm{f}, \mathrm{o}} v_{\mathrm{f}, \mathrm{o}}}$

The boundary conditions for Equations (7-10) in the dimensionless form are given by:

$\mathrm{U}=\mathrm{V}=\frac{\partial \theta}{\partial \mathrm{X}}=0$ at $0 \leq \mathrm{Y} \leq 1$ and $\mathrm{X}=0,1$

$\mathrm{U}=\mathrm{V}=0, \theta=1$ at $\mathrm{Y}=0$ and $0 \leq \mathrm{X} \leq 1$

$\mathrm{U}=\mathrm{V}=0, \theta=0$ at $\mathrm{Y}=1$ and $0 \leq \mathrm{X} \leq 1$

The convective heat transfer coefficient on any $x$ at the hot wall is:

$\mathrm{h}=-\left.\mathrm{k}_{\mathrm{nf}} \frac{\partial \mathrm{T}}{\partial \mathrm{y}}\right|_{\mathrm{y}=0}$

and the local Nusselt number is:

$\mathrm{Nu}=\frac{\mathrm{hH}}{\mathrm{k}_{\mathrm{f}}}$

Substituting Equation (13) into Equation (14) and using the dimensionless quantities, the local Nusselt number along the bottom wall can be written as:

$\mathrm{Nu}=-\left.\left(\frac{\mathrm{k}_{\mathrm{nf}}}{\mathrm{k}_{\mathrm{f}}}\right) \frac{\partial \theta}{\partial \mathrm{Y}}\right|_{\mathrm{Y}=0}$

where $\mathrm{k}_{\mathrm{nf}}$ is calculated using Equation (22) in constant properties model and is calculated from Equation (27) in variable properties model. Finally, the average Nusselt number is determined from:

$\mathrm{Nu}_{\mathrm{avg}}=\int_{0}^{1} \mathrm{NudX}$
Also, the average Nusselt number ratio is defined as:

$$
\mathrm{Nu}_{\text {avg }}^{*}=\mathrm{Nu}_{\text {avg,nf }} / \mathrm{Nu}_{\text {avg,f }}
$$

\section{THERMOPHYSICAL PROPERTIES OF NANOFLUIDS}

The aim of this work is examination of heat transfer characteristics of $\mathrm{Al}_{2} \mathrm{O}_{3}$-EG-water nanofluid using temperature dependent models for properties. However, to show the importance of variation of properties, the results are compared with those of the constant properties models. In this section both variable and constant properties models used in this study are introduced.

4. 1. Constant Properties Models The nanofluids density, validated experimentally for $\mathrm{Al}_{2} \mathrm{O}_{3}$-water nanofluid by Pak and Cho [25], is given by:

$\rho_{\mathrm{nf}}=\Phi \rho_{\mathrm{P}}+(1-\Phi) \rho_{\mathrm{f}}$

The specific heat and thermal expansion coefficient of nanofluids proposed by $[26,4]$, respectively, are:

$\left(\rho c_{\mathrm{p}}\right)_{\mathrm{nf}}=(1-\Phi)\left(\rho \mathrm{c}_{\mathrm{p}}\right)_{\mathrm{f}}+\Phi\left(\rho \mathrm{c}_{\mathrm{p}}\right)_{\mathrm{p}}$

$(\rho \beta)_{\mathrm{nf}}=(1-\Phi)(\rho \beta)_{\mathrm{f}}+\Phi(\rho \beta)_{\mathrm{p}}$

The nanofluid viscosity is estimated by the following correlation developed by Brinkman [27] as:

$\mu_{\mathrm{nf}}=\frac{\mu_{\mathrm{f}}}{(1-\Phi)^{2.5}}$

For thermal conductivity of nanofluids numerous theoretical studies have been conducted dating back to the classical work of Maxwell. Maxwell's model states that the nanofluids thermal conductivity depends on the thermal conductivity of both nanoparticles and the base fluid as well as the volume fraction of nanoparticles. Accordingly, the nanofluid thermal conductivity, given by Wang et al. [28], is:

$\mathrm{k}_{\mathrm{nf}, \text { Maxwell }}=\frac{\mathrm{k}_{\mathrm{p}}+2 \mathrm{k}_{\mathrm{f}}-2 \Phi\left(\mathrm{k}_{\mathrm{f}}-\mathrm{k}_{\mathrm{p}}\right)}{\mathrm{k}_{\mathrm{p}}+2 \mathrm{k}_{\mathrm{f}}+\Phi\left(\mathrm{k}_{\mathrm{f}}-\mathrm{k}_{\mathrm{p}}\right)} \mathrm{k}_{\mathrm{f}}$

To evaluate the properties of the base fluid (mixture of EG and water) for constant properties models:

$\rho_{\mathrm{f}}=\xi \rho_{\mathrm{EG}}+(1-\xi) \rho_{\mathrm{w}}$

$(\rho \eta)_{\mathrm{f}}=\xi(\rho \eta)_{\mathrm{EG}}+(1-\xi)(\rho \eta)_{\mathrm{w}}$

where $\eta$ is the fluid thermophysical property and $\xi$ is Ethylene Glycol volumetric concentration in the mixture and is equal to 0.578 for $60: 40 \mathrm{EG}-\mathrm{w}$ (by mass) mixture [29]. The properties of nanoparticles, Ethylene Glycol and water at reference temperature are presented in Table 1. 
TABLE 1. Properties of nanoparticles, EG and water at reference temperature of $300 \mathrm{~K}[30]$.

\begin{tabular}{lccc}
\hline Properties & $\mathbf{A l}_{2} \mathbf{O}_{3}$ & EG & Water \\
\hline$\rho\left(\mathrm{kg} \mathrm{m}^{-3}\right)$ & 3970 & 1114.4 & 997 \\
$c_{p}\left(\mathrm{~J} \mathrm{~kg}^{-1} \mathrm{~K}^{-1}\right)$ & 765 & 2415 & 4179 \\
$\mu \times 10^{4}(\mathrm{~Pa} \mathrm{~s})$ & - & 157 & 8.55 \\
$\beta \times 10^{5}\left(\mathrm{~K}^{-1}\right)$ & 0.846 & 65 & 27.61 \\
$k\left(\mathrm{~W} \mathrm{~m}^{-1} \mathrm{~K}^{-1}\right)$ & 36 & 0.252 & 0.613 \\
\hline
\end{tabular}

4. 2. Variable Properties Models As described by Vajjha et al. [24], the best correlation for the density of $\mathrm{Al}_{2} \mathrm{O}_{3}$ nanoparticles dispersed in 60:40 EG-w as the base fluid is presented by Equation (18). The base fluid variable density proposed by [31] is:

$\rho_{\mathrm{f}}=-2.43 \times 10^{-3} \mathrm{~T}^{2}+0.96216 \mathrm{~T}+1009.9261$

The specific heat of $\mathrm{Al}_{2} \mathrm{O}_{3}$-EG-W nanofluid for $60: 40$ EG-w given by Vajjha and Das [23] is:

$\frac{\mathrm{c}_{\mathrm{p}, \mathrm{nf}}}{\mathrm{c}_{\mathrm{p}, \mathrm{f}}}=\frac{8.911 \times 10^{-4} \mathrm{~T}+0.5179 \frac{\mathrm{c}_{\mathrm{p}, \mathrm{p}}}{\mathrm{c}_{\mathrm{p}, \mathrm{f}}}}{0.425+\Phi}$

Sahoo et al. [21] measured the viscosity of $\mathrm{Al}_{2} \mathrm{O}_{3}$-EG-W nanofluid for volume fractions up to 0.1 . For the temperature range of 273 to $363 \mathrm{~K}$, they proposed:

$\mu_{n f}=2.392 \times 10^{-7} \exp \left(\frac{2903}{T}+12.65 \Phi\right)$

Vajjha and Das [22] measured the thermal conductivity of $\mathrm{Al}_{2} \mathrm{O}_{3}$-EG-w nanofluid for 60:40 EG-w. They developed a thermal conductivity model as a two-term function in the temperature range of 298 to $363 \mathrm{~K}$ as:

$\mathrm{k}_{\mathrm{nf}}=\frac{\mathrm{k}_{\mathrm{p}}+2 \mathrm{k}_{\mathrm{f}}-2\left(\mathrm{k}_{\mathrm{f}}-\mathrm{k}_{\mathrm{p}}\right) \Phi}{\mathrm{k}_{\mathrm{p}}+2 \mathrm{k}_{\mathrm{f}}+2\left(\mathrm{k}_{\mathrm{f}}-\mathrm{k}_{\mathrm{p}}\right) \Phi} \mathrm{k}_{\mathrm{f}}+$

$5 \times 10^{4} \mathrm{~B} \Phi \rho_{\mathrm{f}} \mathrm{c}_{\mathrm{p}, \mathrm{f}} \sqrt{\frac{\kappa \mathrm{T}}{\rho_{\mathrm{p}} \mathrm{d}_{\mathrm{p}}}} \mathrm{f}(\mathrm{T}, \Phi)$

where $\mathrm{f}(\mathrm{T}, \Phi)$ is:

$\mathrm{f}(\mathrm{T}, \Phi)=\left(2.8217 \times 10^{-2} \Phi+3.917 \times 10^{-3}\right) \frac{\mathrm{T}}{\mathrm{T}_{\mathrm{o}}}$

$+\left(-3.0669 \times 10^{-2} \Phi-3.91123 \times 10^{-3}\right)$

$\mathrm{B}$ is fraction of the liquid volume which travels with a particle and for nanofluid comprised of $\mathrm{Al}_{2} \mathrm{O}_{3}$ nanoparticles is:

$\mathrm{B}=8.4407(100 \Phi)^{-1.07304}$

The first term in Equation (27-a) is called the static part and the second term takes into account the effect of particle size, particle volume fraction, temperature and properties of the base fluid as well as the nanoparticles subjected to Brownian motion.

To the best of our knowledge, there is no correlation for thermal expansion coefficient of $\mathrm{Al}_{2} \mathrm{O}_{3}-\mathrm{EG}-\mathrm{W}$ nanofluid as a function of temperature; thus in this study, Equation (20) has been used as a base to obtain a variable thermal expansion coefficient. For this purpose, initially the values of density and thermal expansion coefficient of EG and water taken from [30], within the temperature range of 295-320 K, have been curve fitted. The results are:

$$
\begin{array}{lc}
\rho_{E G}=4.667 \times 10^{-4} T^{3}-0.4515 T^{2}+144.1 T & \mathrm{R}^{2}=1 \\
-1.408 \times 10^{4} & \\
\beta_{\mathrm{EG}}=6.5 \times 10^{-4} & \\
\rho_{\mathrm{w}}=-0.003404 T^{2}+1.726 T+785.1 & \mathrm{R}^{2}=0.997 \\
\beta_{\mathrm{w}}=\left(-0.06107 T^{2}+45.9 T-7999\right) \times 10^{-6} & \mathrm{R}^{2}=1
\end{array}
$$

Then, the thermal expansion coefficient of the EG-w mixture has been obtained using Equation (23-b); and finally by substituting the results in Equation (20) the thermal expansion coefficient of the nanofluid has been obtained.

The other properties of the base fluid are [31]:

$$
\begin{aligned}
& \mu_{\mathrm{f}}=5.55 \times 10^{-7} \exp \left(\frac{2664}{\mathrm{~T}}\right) \\
& \mathrm{k}_{\mathrm{f}}=-3.196 \times 10^{-6} \mathrm{~T}^{2}+2.512 \times 10^{-3} \mathrm{~T}-0.10541 \\
& \mathrm{c}_{\mathrm{p}, \mathrm{f}}=4.2483 \mathrm{~T}+1882.4
\end{aligned}
$$

\section{NUMERICAL PROCEDURE}

The governing equations and the associated boundary conditions have been solved numerically using the finite volume method. The diffusion terms in the governing equations have been discretized using a second-order central difference scheme; while a hybrid scheme (a combination of the central difference scheme and the upwind scheme) has been employed to approximate the convection terms. A staggered grid system together with the SIMPLER algorithm has been adopted to solve for the pressure and the velocity components. The coupled set of discretized equations has been solved iteratively using the TDMA method [32]. To obtain converged solution, an under-relaxation scheme has been employed.

\section{BENCHMARKING OF THE CODE}

In order to validate the numerical procedure and as a test case, the geometry and conditions of Ghasemi and Aminossadati [33] have been considered. The test case is a two-dimensional square enclosure with an inclination angle; where the inclination angle is considered zero. Its horizontal walls have different 
constant temperatures and the vertical walls are adiabatic (Figure 2-a). The enclosure is filled with $\mathrm{CuO}$ water nanofluid. Figure 2-b shows the average Nusselt number on the hot wall for $\mathrm{Ra}=10^{5}$ and $\mathrm{Ra}=10^{6}$ obtained by the results of the computer code of this study compared with those of Ghasemi and Aminossadati [33]. It should be noted that the values for average Nusselt numbers have been picked from a curve in [33] with ultimate care. As seen, for every volume fraction of nanoparticles good agreement exists between the average Nusselt number obtained in this study and that of Ghasemi and Aminossadati [33].

\section{GRID INDEPENDENCE STUDY}

In order to determine a proper grid for the numerical simulation, a grid independence study is undertaken. Six different uniform grids, namely, $41 \times 41,61 \times 61,81 \times$ $81,101 \times 101,121 \times 121$ and $141 \times 141$ are employed to simulate the natural convection inside the cavity for $\Phi=0.03$ at $\mathrm{Ra}=10^{6}$. The variations of the average Nusselt number with the number of grid points are depicted in Figure 3. As it can be observed from this figure, a $121 \times 121$ uniform grid is sufficiently fine to ensure a grid independent solution. Hence, this grid is used to perform all the subsequent calculations.

\section{RESULTS AND DISCUSSION}

The range of Rayleigh number and volume fraction of nanoparticles are $\mathrm{Ra}=10^{5}-10^{7}$ and $0 \leq \Phi \leq 0.05$, respectively. The top wall temperature is maintained at the reference temperature i.e., at $300 \mathrm{~K}$, whereas the temperature of the bottom wall varies in term of Rayleigh number. All the thermophysical properties of the nanofluid and base fluid are considered variable. In natural convection of nanofluids, to investigate the flow strength and heat transfer process, the term $\rho \psi$ is more important than stream function $(\psi)$. Figure 4 portrays the flow strength $(\rho \psi)$ for various Rayleigh numbers $\left(\mathrm{Ra}=10^{5}-10^{7}\right)$ for both the nanofluid $(\Phi=0.05)$ and pure fluid, respectively. The flow is characterized by two symmetrical circulating cells formed in opposite directions within the enclosure. In fact, the fluid rises in the middle from the bottom hot wall towards the top cold wall and then descends on the sides of the enclosure. Also, it is evident that the addition of nanoparticles results in decreasing the intensity of the flow strength. This can clearly be demonstrated by a comparison of the magnitude of the maximum flow strength of both the nanofluid and pure fluid in Figure 4 (i.e., circulating rolls strength) due to the higher viscosity of the nanofluid.
In addition, increasing Ra results in higher intensity of the flow strength. This, in turn, strengthens the natural convection and improves the heat transfer rate for the nanofluid within the enclosure. As shown in Figure 5, by increasing the volume fraction of nanoparticles, velocity decreases which indicates that the fluid becomes more viscous. Figure 6 presents isotherms for the Rayleigh-Bénard convection problem for the base fluid and nanofluid ( $\Phi=0.05$ ).

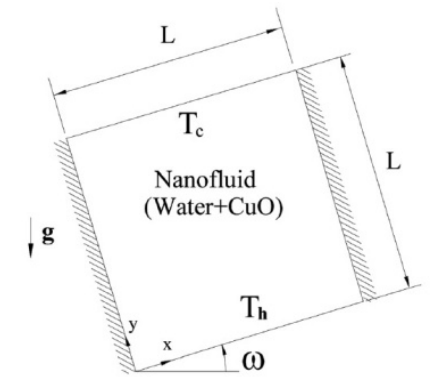

(a)

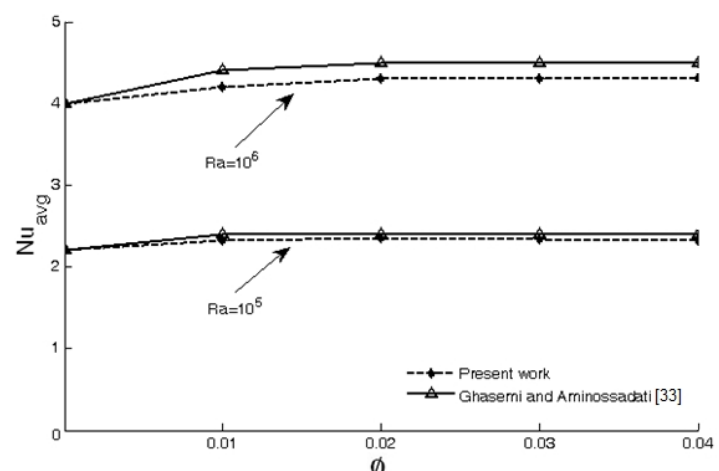

(b)

Figure 2. a) Domain and boundary conditions for the test case [33] b) The average Nusselt number in term of volume fraction of nanoparticles at different Ra: Comparison of present results with the results of Ghasemi and Aminossadati [33].

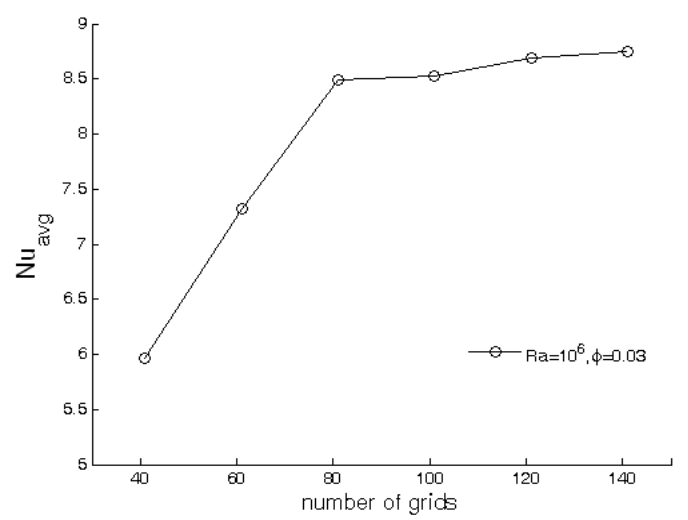

Figure 3. Effect of the grid density on the average Nusselt number for $\mathrm{Ra}=10^{6}$ and $\Phi=0.03$. 


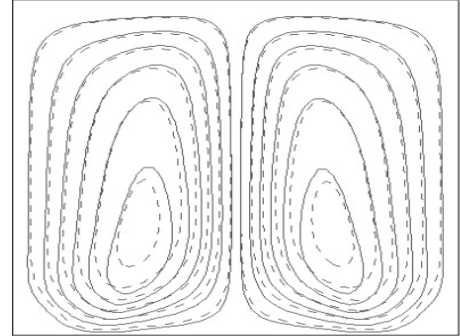

$$
\mathrm{Ra}=10^{5}
$$

pure fluid: $(\rho \psi)_{\max }=11572.965$

nanofluid: $(\rho \psi)_{\max }=10654.519$

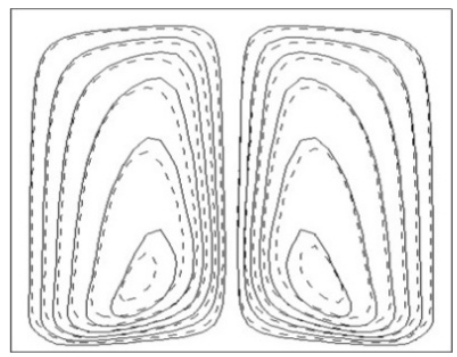

$$
\mathrm{Ra}=10^{6}
$$

pure fluid: $(\rho \psi)_{\max }=32817.846$

nanofluid: $(\rho \psi)_{\max }=31219.069$

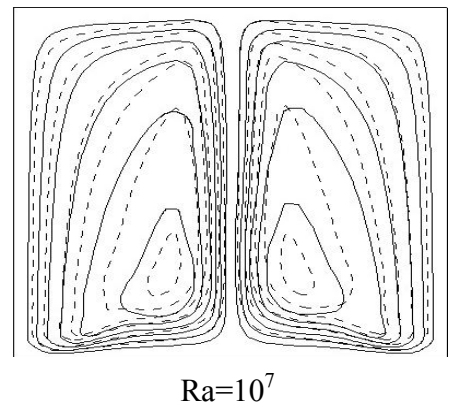

pure fluid: $(\rho \psi)_{\max }=86592.834$

nanofluid: $(\rho \psi)_{\max }=67338.197$

Figure 4. Flow strength for both nanofluid with $\Phi=0.05$ (dashed lines) and pure fluid (lines).

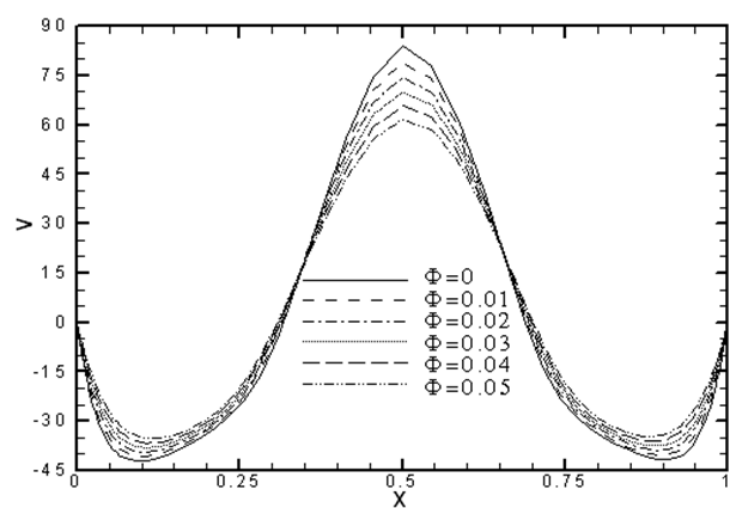

Figure 5. Variation of $y$-velocity at the midsection of the enclosure for various $\Phi$ at $\mathrm{Ra}=10^{5}$.

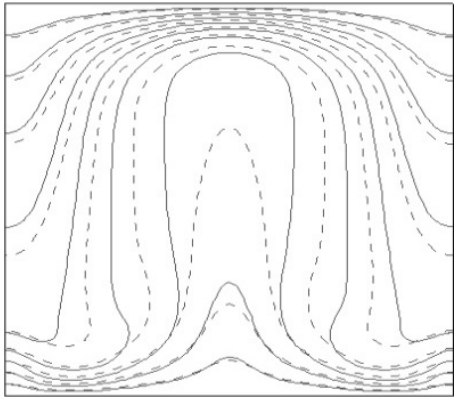

$\mathrm{Ra}=10^{5}$

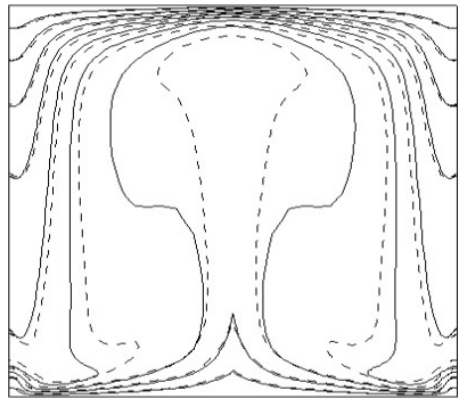

$\mathrm{Ra}=10^{6}$

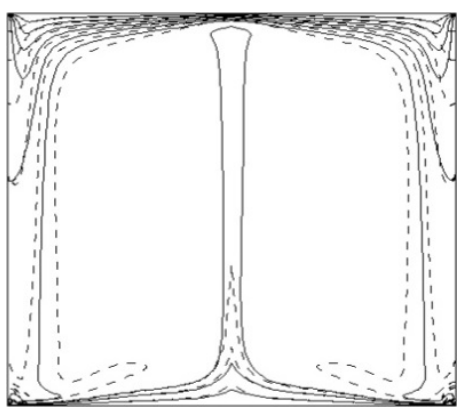

$\mathrm{Ra}=10^{7}$

Figure 6. Isotherms for both the nanofluid with $\Phi=0.05$ (dashed lines) and pure fluid (lines).

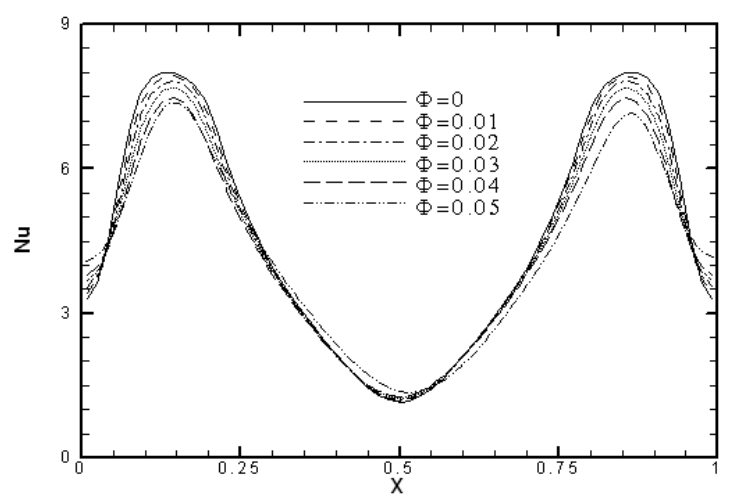

(a) 


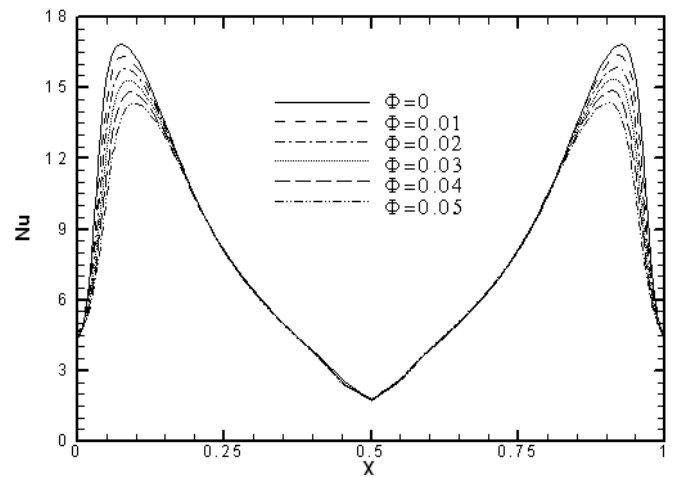

(b)

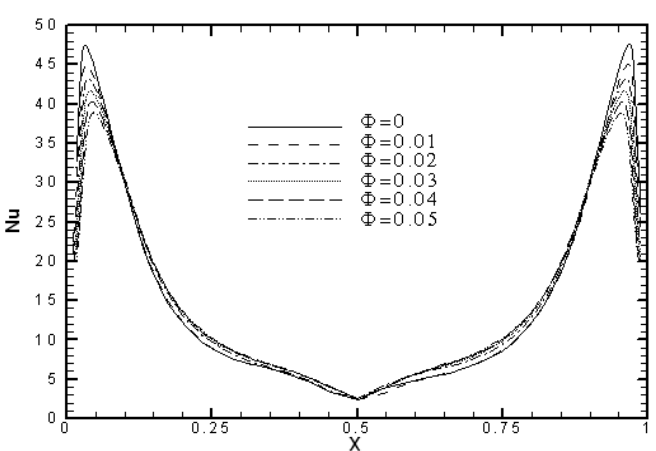

(c)

Figure 7. Nu along the hot wall: (a) $\mathrm{Ra}=10^{\circ}$, (b) $\mathrm{Ra}=10^{\circ}$, (c) $\mathrm{Ra}=10^{7}$

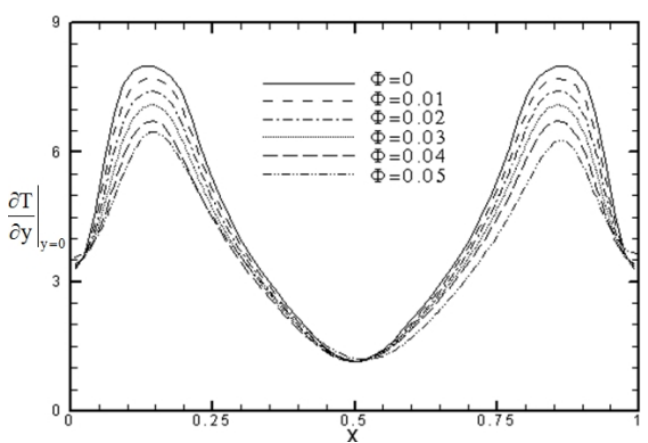

(a)

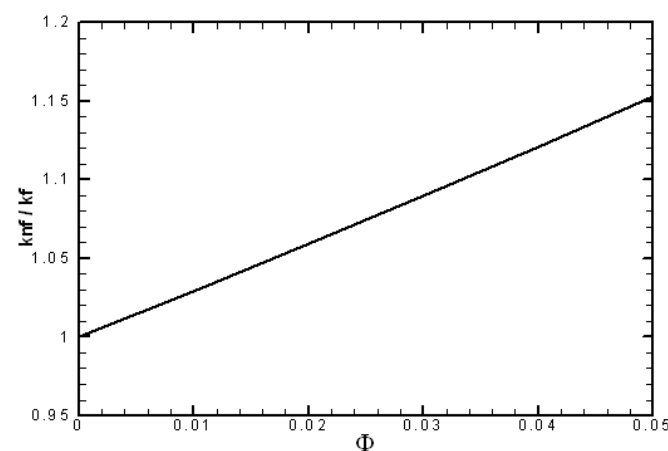

(b)

Figure 8. Variation of: (a) temperature gradient on the hot wall, (b) Thermal conductivity ratio, for various $\Phi$ at $\mathrm{Ra}=10^{5}$.
As observed from these isotherms, the basic feature of Rayleigh-Bénard problem such as the appearance of the thermal plume and the two thermal boundary layers at the top and bottom walls, are depicted accurately. Besides, it is shown that near the top and bottom walls the isotherms are almost horizontal, which demonstrates the dominance of the conduction heat transfer whereas in the other regions, the isotherms have plume behavior due to the dominance of convection. According to this figure, by adding nanoparticles the plume strength (or plume height) decreases. As mentioned before, increasing the volume fraction of nanoparticles causes the fluid velocity and flow strength to decrease, which yields some reduction in convection (reflected by shorter plume height) as depicted in Figure 6.

Figure 7 shows the variation of the local Nusselt number $(\mathrm{Nu})$ along the hot wall for $\mathrm{Ra}=10^{5}-10^{7}$ and 0 $\leq \Phi \leq 0.05$. A symmetrical variation with a minimum in the center of the hot wall can be observed for both the pure fluid and the nanofluid. This can be explained by the formation of two opposite circulating cells within the enclosure. Also, it is seen that an increase in the volume fraction of nanoparticles leads to a reduction in Nusselt number at all Rayleigh numbers. Although most of the previous studies indicated Nusselt number increase with nanoparticles volume fraction, but according to the present work, there are contrary results which are in agreement with results of Abu-Nada [19]. Natural convection heat transfer is affected by nanofluid properties and specifically by nanofluid viscosity and thermal conductivity [18]. In general, adding nanoparticles to the base fluid has two opposite effects on the Nusselt number: a positive effect that is determined by the presence of high thermal conductivity nanoparticles (as shown in Figure 8-b), and an adverse effect promoted by the high level of viscosity experienced due to the existence of nanoparticles. In effect, at high Rayleigh numbers, the heat transfer in Rayleigh-Bénard natural convection is dominated by convection. Therefore, for $\mathrm{Ra} \geq 10^{5}$, increasing the nanofluid viscosity deteriorates convection, and consequently reduces the temperature gradient (as shown in Figure 8-a); Increase in nanofluid viscosity is accompanied by an increase in thermal boundary layer thickness near the hot wall, and this increase is interpreted as a reduction in temperature gradients. This is related to the deceleration of convection currents near the bottom heated wall which reduces the role of Brownian motion in enhancing thermal conductivity. However, heat transfer enhancement due to the high thermal conductivity of nanoparticles is smaller than its reduction due to increase of the nanofluid viscosity.

According to Equation (15), the Nusselt number is influenced by temperature gradient at the bottom hot wall and the thermal conductivity ratio. According to Figure 8, there is a $15.3 \%$ increase for thermal conductivity ratio and a maximum $19.1 \%$ decrease for 
temperature gradient for the nanofluid with $\Phi=0.05$ in comparison with pure fluid at $\mathrm{Ra}=10^{5}$. Figure 9 illustrates the average Nusselt number and Nusselt number ratio along the hot wall. As would be expected, the average Nusselt number for the nanofluid increases with $\mathrm{Ra}$ so that at $\Phi=0.05$, the average Nusselt numbers for $\mathrm{Ra}=10^{6}$ and $\mathrm{Ra}=10^{7}$ are 1.99 and 3.55 times of those for $\mathrm{Ra}=10^{5}$ respectively. It is shown that for all $\mathrm{Ra}$, a decrease in Nusselt number occurs for an increase in volume fraction of nanoparticles. It is worth mentioning that the case of $\mathrm{Ra}=10^{7}$ experiences less deterioration in Nusselt number when compared to $\mathrm{Ra}=10^{5}$ and $10^{6}$ cases (Figure 9-b). In fact, for $\mathrm{Ra}=10^{7}$, the flow strength and subsequently the inertia forces are larger than those of $\mathrm{Ra}=10^{5}$ and $10^{6}$. This causes the adverse effect of nanoparticles to become weaker at $\mathrm{Ra}=10^{7}$, which causes less reduction in Nusselt number compared to lower Rayleigh numbers.

In order to verify the observed trend of changing $\mathrm{Nu}_{\text {avg }}$ with $\mathrm{Ra}$ and $\Phi$, the values of $\mathrm{Nu}_{\text {avg }}$ obtained in the present study have been compared with experimental results of Wen and Ding [34] in Figure 10. Although, the nanoparticles or the base fluid used in the mentioned experimental work differs from what has been used in the present study, the trend of changes is similar. This similarity is another verification of the results of this study.

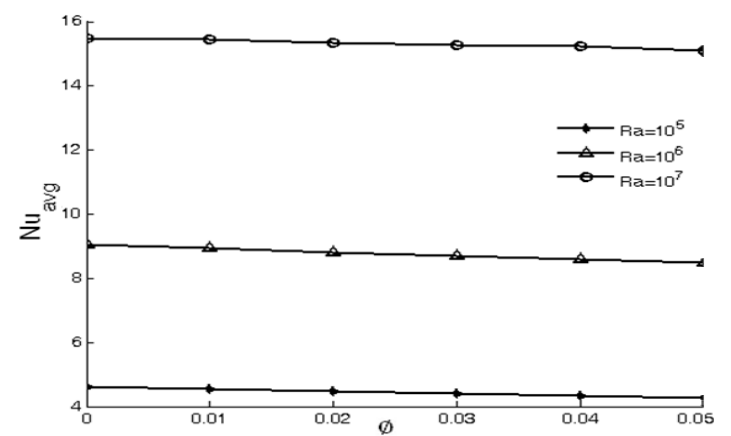

(a)

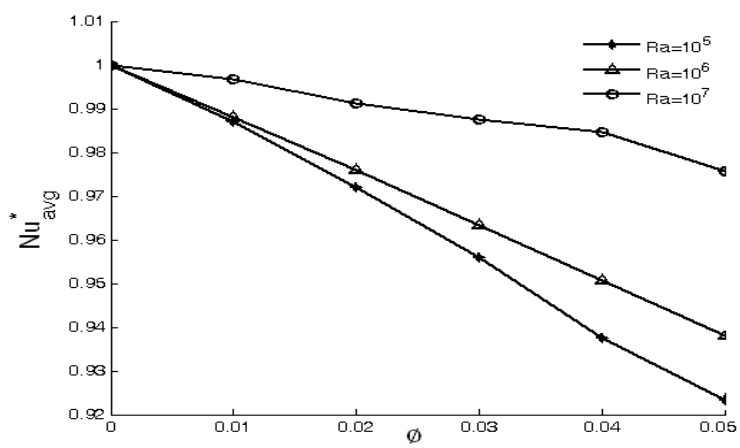

(b)

Figure 9. Effect of volume fraction of nanoparticles and Rayleigh number on average Nusselt number: (a) Average Nusselt number, and (b) Nusselt number ratio.

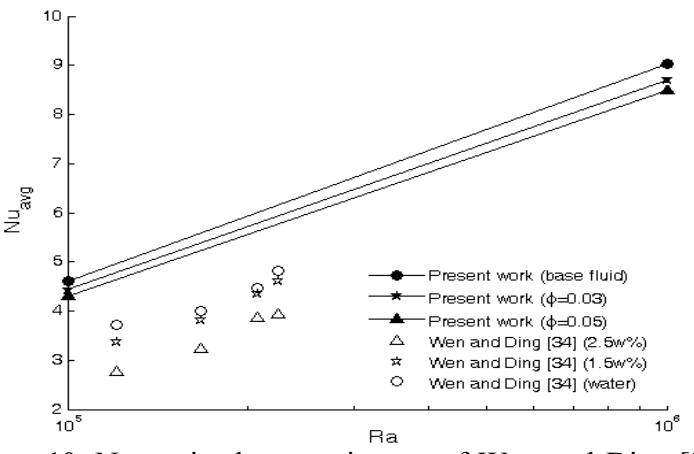

Figure 10. Nuavg in the experiments of Wen and Ding [34] and in the present numerical study.

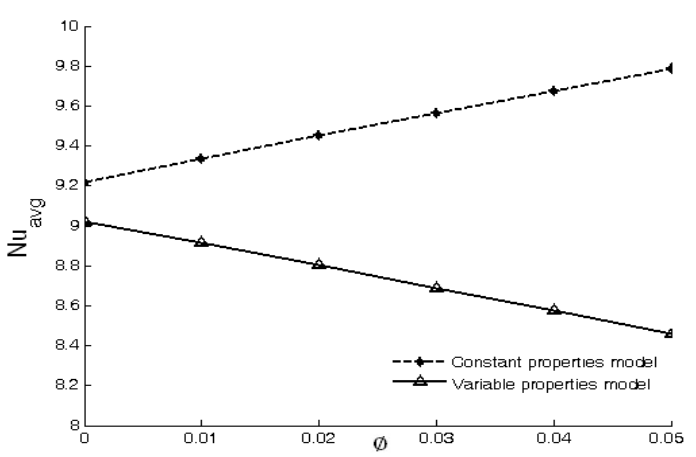

Figure 11. Variations of average Nusselt number with respect to volume fraction of nanoparticles for $\mathrm{Ra}=10^{6}$ : Comparison between constant properties model and variable properties model.

Figure 11 shows $\mathrm{Nu}_{\text {avg }}$ for $\mathrm{Ra}=10^{6}$ obtained in simulations for variable as well as constant properties models of this study. The properties in constant properties model (given by Equations 18-23) have been evaluated at the reference temperature of $300 \mathrm{~K}$. According to Figure 11, as $\Phi$ increases $\mathrm{Nu}_{\text {avg }}$ increases in the constant properties model, but decreases in the variable properties model. The results for constant properties model are in agreement with those of previous numerical [4-7] and analytical [10] studies, in which constant properties have been used. However, this trend contradicts the results of the present study for variable properties model and disagrees with experimental results reported by [13-15]. This distinction is due to underestimation of viscosity of the nanofluid in the constant properties models and indicates the important effects of temperature dependency of thermophysical properties.

\section{CONCLUSIONS}

Rayleigh-Bénard natural convection in an enclosure filled with $\mathrm{Al}_{2} \mathrm{O}_{3}$-EG-water nanofluid using variable properties has been studied numerically. Various nanoparticles volume fractions and Rayleigh numbers 
have been considered and the flow and temperature fields as well as heat transfer characteristics have been studied. The results showed for $\mathrm{Ra} \geq 10^{4}$ and as the volume fraction of nanoparticles increases, deterioration in heat transfer occurs compared to the base fluid heat transfer. This decrease is linked to increased viscosity as volume fraction of nanoparticles increases. However, by studying the Nusselt number ratio, it was noticed that this reduction is more severe at $\mathrm{Ra}=10^{5}$ and $\mathrm{Ra}=10^{6}$ compared to $\mathrm{Ra}=10^{7}$. The heat transfer results of this study were verified by making comparison with previous experimental results. Also, the heat transfer results for variable properties models were compared with those obtained for constant properties models. Similar with the results of some previous numerical works obtained using constant properties, the constant properties models of this study predicted heat transfer enhancement as $\Phi$ increased.

\section{ACKNOWLEDGMENT}

The authors wish to thank the Research \& Technology Administration and Energy Research Institute of the University of Kashan for their support regarding this research (Grant No. 255905).

\section{REFERENCES}

1. Heyhat, M. and Kowsary, F., "Numerical simulation of forced convection of nanofluids by a two-component nonhomogenious model", International Journal of Engineering, Transactions A: Basics, Vol. 23, No. 1, (2010), 89-99.

2. Daungthongsuk, W. and Wongwises, S., "A critical review of convective heat transfer of nanofluids", Renewable and Sustainable Energy Reviews, Vol. 11, No. 5, (2007), 797-817.

3. Davarnejad, R., Barati, S. and Zakeri, M., "Simulation of convective heat transfer of a nanofluid in a circular crosssection", International Journal of Engineering-Transactions C: Aspects, Vol. 26, No. 6, (2012), 571.

4. Khanafer, K., Vafai, K. and Lightstone, M., "Buoyancy-driven heat transfer enhancement in a two-dimensional enclosure utilizing nanofluids", International Journal of Heat and Mass Transfer, Vol. 46, No. 19, (2003), 3639-3653.

5. Arefmanesh, A., Amini, M., Mahmoodi, M. and Najafi, M., "Buoyancy-driven heat transfer analysis in two-square duct annuli filled with a nanofluid", European Journal of Mechanics-B/Fluids, Vol. 33, (2012), 95-104

6. Sheikhzadeh, G., Arefmanesh, A., Kheirkhah, M. and Abdollahi, R., "Numerical study of natural convection in an inclined cavity with partially active side walls filled with cu-water nanofluid", International Journal of Engineering-Transactions B: Applications, Vol. 24, No. 3, (2011), 279.

7. Sheikhzadeh, G. A., Arefmanesh, A. and Mahmoodi, M., "Numerical study of natural convection in a differentially-heated rectangular cavity filled with $\mathrm{TiO}_{2}$-water nanofluid", Journal of Nano Research, Vol. 13, (2011), 75-80.

8. Hwang, K. S., Lee, J.-H. and Jang, S. P., "Buoyancy-driven heat transfer of water-based $\mathrm{Al}_{2} \mathrm{O}_{3}$ nanofluids in a rectangular cavity", International Journal of Heat and Mass Transfer, Vol. 50, No. 19, (2007), 4003-4010.

9. Kim, J., Kang, Y. T. and Choi, C. K., "Analysis of convective instability and heat transfer characteristics of nanofluids", Physics of Fluids, Vol. 16, No. 7, (2004), 2395-2401.

10. Aminossadati, S. and Ghasemi, B., "Natural convection cooling of a localised heat source at the bottom of a nanofluid-filled enclosure", European Journal of Mechanics-B/Fluids, Vol. 28, No. 5, (2009), 630-640.

11. Santra, A. K., Sen, S. and Chakraborty, N., "Study of heat transfer characteristics of copper-water nanofluid in a differentially heated square cavity with different viscosity models", Journal of Enhanced Heat Transfer, Vol. 15, No. 4, (2008).

12. Ho, C.-J., Chen, M. and Li, Z., "Numerical simulation of natural convection of nanofluid in a square enclosure: Effects due to uncertainties of viscosity and thermal conductivity", International Journal of Heat and Mass Transfer, Vol. 51, No. 17, (2008), 4506-4516.

13. Wen, D. and Ding, Y., "Experimental investigation into convective heat transfer of nanofluids at the entrance region under laminar flow conditions", International Journal of Heat and Mass Transfer, Vol. 47, No. 24, (2004), 5181-5188.

14. Putra, N., Roetzel, W. and Das, S. K., "Natural convection of nano-fluids", Heat and Mass Transfer, Vol. 39, No. 8-9, (2003), 775-784.

15. Li, C. H. and Peterson, G., "Experimental studies of natural convection heat transfer of $\mathrm{Al}_{2} \mathrm{O}_{3}$ di water nanoparticle suspensions (nanofluids)", Advances in Mechanical Engineering, Vol. 2010, (2009).

16. Ho, C., Liu, W., Chang, Y. and Lin, C., "Natural convection heat transfer of alumina-water nanofluid in vertical square enclosures: An experimental study", International Journal of Thermal Sciences, Vol. 49, No. 8, (2010), 1345-1353.

17. Nnanna, A. A. "Experimental model of temperature-driven nanofluid", Transactions-American Society of Mechanical Engineers Journal of Heat Transfer, Vol. 129, No. 6, (2007), 697.

18. Khanafer, K. and Vafai, K., "A critical synthesis of thermophysical characteristics of nanofluids", International Journal of Heat and Mass Transfer, Vol. 54, No. 19, (2011), 4410-4428.

19. Abu-Nada, E., "Rayleigh-Bénard convection in nanofluids: Effect of temperature dependent properties", International Journal of Thermal Sciences, Vol. 50, No. 9, (2011), 17201730 .

20. Abu-Nada, E. and Chamkha, A. J., "Effect of nanofluid variable properties on natural convection in enclosures filled with a CuO-eg-water nanofluid", International Journal of Thermal Sciences, Vol. 49, No. 12, (2010), 2339-2352.

21. Sahoo, B. C., Vajjha, R. S., Ganguli, R., Chukwu, G. A. and Das, D. K., "Determination of rheological behavior of aluminum oxide nanofluid and development of new viscosity correlations", Petroleum Science and Technology, Vol. 27, No. 15, (2009), 1757-1770.

22. Vajjha, R. S. and Das, D. K., "Experimental determination of thermal conductivity of three nanofluids and development of new correlations", International Journal of Heat and Mass Transfer, Vol. 52, No. 21, (2009), 4675-4682.

23. Vajjha, R. S. and Das, D. K., "Specific heat measurement of three nanofluids and development of new correlations", Journal of Heat Transfer, Vol. 131, No. 7, (2009).

24. Vajjha, R., Das, D. and Mahagaonkar, B., "Density measurement of different nanofluids and their comparison with theory", Petroleum Science and Technology, Vol. 27, No. 6, (2009), 612-624. 
25. Pak, B. C. and Cho, Y. I., "Hydrodynamic and heat transfer study of dispersed fluids with submicron metallic oxide particles", Experimental Heat Transfer an International Journal, Vol. 11, No. 2, (1998), 151-170.

26. Xuan, Y. and Roetzel, W., "Conceptions for heat transfer correlation of nanofluids", International Journal of Heat and Mass Transfer, Vol. 43, No. 19, (2000), 3701-3707.

27. Brinkman, H., "The viscosity of concentrated suspensions and solutions", The Journal of Chemical Physics, Vol. 20, (1952), 571.

28. Wang, X., Xu, X. and S. Choi, S. U., "Thermal conductivity of nanoparticle-fluid mixture", Journal of Thermophysics and Heat Transfer, Vol. 13, No. 4, (1999), 474-480.

29. ASHRAE, P., "Ashrae handbook-fundamentals", American Society of Heating Refrigerating and Air-Conditioning Engineers, Atlanta, Vol., No., (2005).
30. Incropera, F. P. and Dewitt, D. P., "Introduction to heat transfer ", John WHey \& Sons. New York. NY, (1996)

31. Vajjha, R. S., Das, D. K. and Kulkarni, D. P., "Development of new correlations for convective heat transfer and friction factor in turbulent regime for nanofluids", International Journal of Heat and Mass Transfer, Vol. 53, No. 21, (2010), 4607-4618.

32. Patankar, S. V., "Numerical heat transfer and fluid flow", Taylor \& Francis, (1980).

33. Ghasemi, B. and Aminossadati, S., "Natural convection heat transfer in an inclined enclosure filled with a water-cuo nanofluid", Numerical Heat Transfer, Part A: Applications, Vol. 55, No. 8, (2009), 807-823.

34. Wen, D. and Ding, Y., "Natural convective heat transfer of suspensions of titanium dioxide nanoparticles (nanofluids)", Nanotechnology, IEEE Transactions on, Vol. 5, No. 3, (2006), 220-227. 
The Effect of Variable Properties on Rayleigh-Benard Convection in an Enclosure Filled with $\mathrm{Al}_{2} \mathrm{O}_{3}$-EG-Water Nanofluid

\author{
G. A. Sheikhzadeh, S. P. Ghaffari, M. M. Fakhari
}

Department of Mechanical Engineering and Energy Research Institute, University of Kashan, Kashan, Iran

PAPER INFO

جكيده

Paper history:

Received 24 March 2013

Received in revised form 16 May 2013

Accepted 20 June 2013

\section{Keywords:}

Nanofluid

Variable properties

Rayleigh-Benard convection

$\mathrm{Al}_{2} \mathrm{O}_{3}$-Ethylene Glycol-water

Enclosure
در مطالعهى حاضر، انتقال حرارت جابهجايى آزاد نانو سيال آب-|تيلنكليكول-آلومينا در يكى محفظهى مستطيلى كه از بإيين

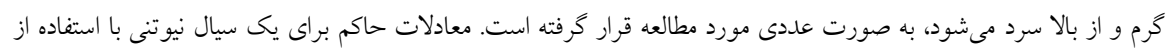

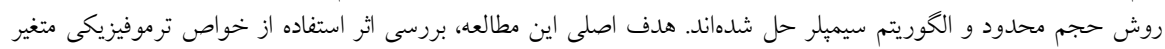

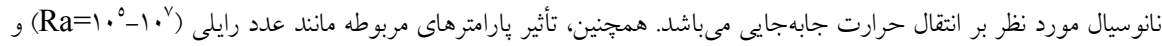

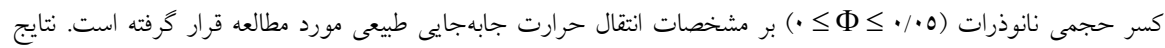

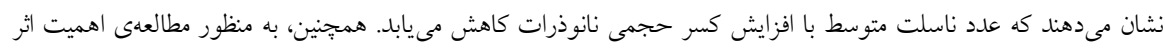

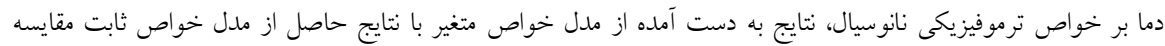
شدهاند. 


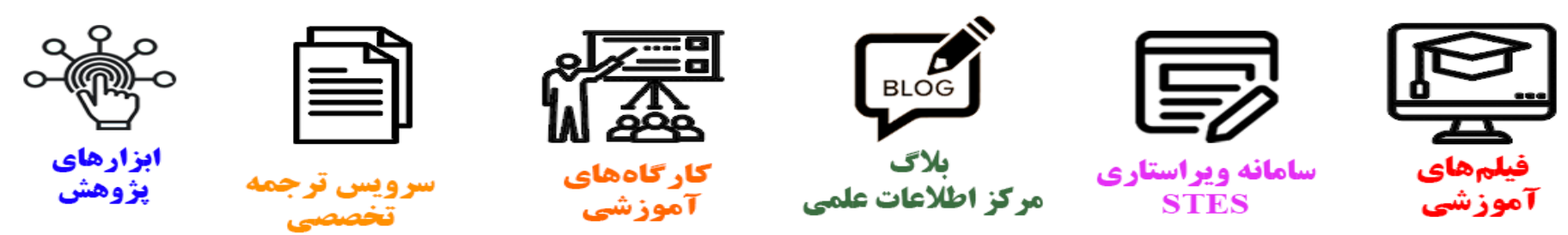

\section{(c)}

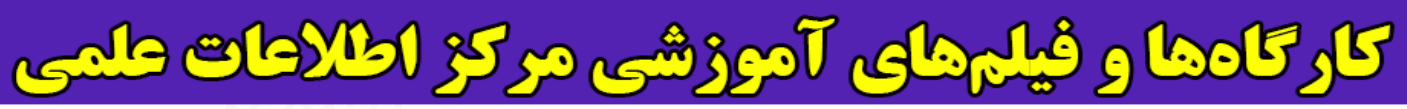
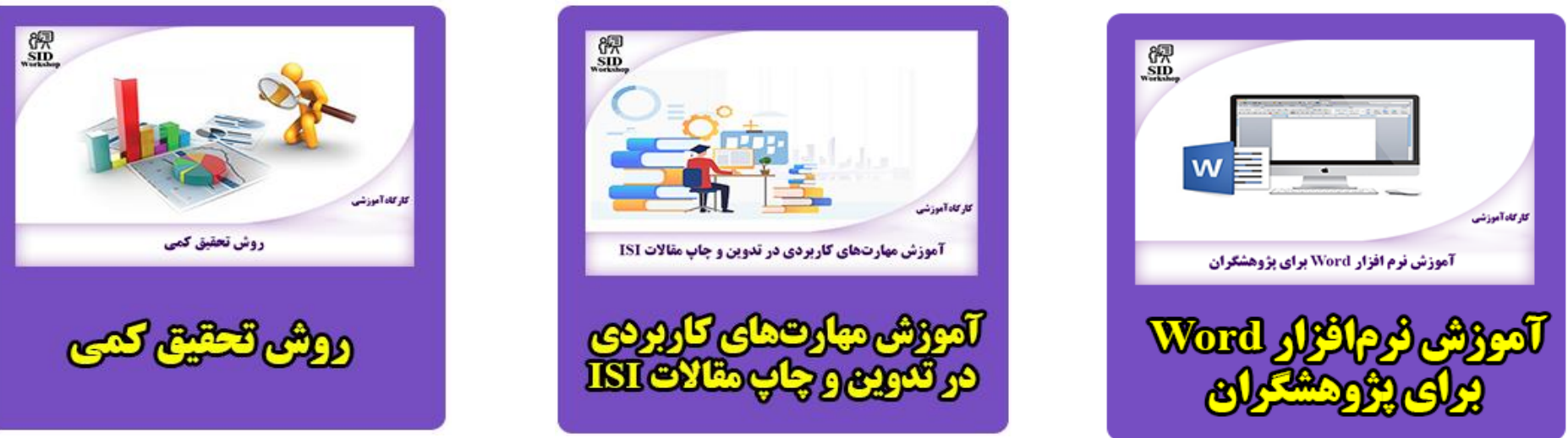